\title{
OILSEED RAPE (BRASSICA NAPUS L.) NUTRITION BY NITROGEN AND PHOSPHORUS AND ITS EFFECT ON YIELD OF SEED, OIL AND HIGHER FATTY ACIDS CONTENT
}

\author{
Mária Vicianová ${ }^{1}$, Ladislav Ducsay ${ }^{1}$, Pavel Ryant², Marek Provazník, \\ Alexandra Zapletalová ${ }^{1}$, Marek Slepčan ${ }^{1}$ \\ ${ }^{1}$ Department of Agrochemistry and Plant Nutrition, Slovak University of Agriculture in Nitra, Tr. A. Hlinku 2, \\ 94976 Nitra, Slovak Republic \\ ${ }^{2}$ Department of Agrochemistry, Soil Science, Microbiology and Plant Nutrition, Faculty of AgriSciences, Mendel \\ University in Brno, Zemědělská 1, 61300 Brno, Czech Republic
}

Link to this article: https://doi.org/10.11118/actaun202068010129

Received: 19. 7. 2019, Accepted: 28. 1. 2020

To cite this article: VICIANOVÁ MÁRIA, DUCSAY LADISLAV, RYANT PAVEL, PROVAZNÍK MAREK, ZAPLETALOVÁ ALEXANDRA, SLEPČAN MAREK. 2020. Oilseed Rape (Brassica Napus L.) Nutrition by Nitrogen and Phosphorus and its Effect on Yield of Seed, Oil and Higher Fatty Acids Content. Acta Universitatis Agriculturae et Silviculturae Mendelianae Brunensis, 68(1): 129-136.

\begin{abstract}
The effect of phosphorus (P) and nitrogen (N) application on yield, oil and fatty acids content (especially oleic acid, linoleic acid and linolenic acid) in rapeseed was investigated in the field experiment. Also effect of weather conditions was evaluated. The polyfactorial trial was realized in experimental years 2013/2014 and 2014/2015 in terms of agricultural cooperative in Mojmírovce. The experiment was based on three variants of fertilization treatments by the block method in three replications. The size of each block was created by plots with size $600 \mathrm{~m}^{2}$. The first level of treatment $1_{0}$ was non-fertilized control. The second level of treatment $2_{\mathrm{u}}$ was fertilized by nitrogen in dose $240 \mathrm{~kg}^{-\mathrm{ha}^{-1}}$. The third level of treatment $3_{\mathrm{p}}$ was fertilized by the same dose of nitrogen $240 \mathrm{~kg} \cdot \mathrm{ha}^{-1}$ and by phosphorus in dose $88 \mathrm{~kg} \cdot \mathrm{ha}^{-1}$. The highest average yield 3.9 tha $^{-1}$ was achieved at treatment 3 , where phosphorus was applied. It means statistically significant yield increase by $30 \%$ compared to treatment $2_{\mathrm{W}}$, where no phosphorus was not applied. There was statistically non-significant difference in oil content, in the range of treatments. The content of oleic acid fluctuated from $63.3 \%$ to $65.9 \%$ and the highest was reached at unfertilized control treatments in both experimental years. The linoleic acid content ranged from $20.3 \%$ to $21.2 \%$ and content of linolenic acid varied between $6.9 \%$ and $8.9 \%$. Application of nitrogen and nitrogen + phosphorus high statistically significant decreased oleic acid content in both experimental years. Opposite effect was observed, where content of linoleic and linolenic acid was high statistically significant increased after nitrogen and nitrogen-phosphorus fertilization. Effect of unequal weather conditions and treatments of nitrogen and nitrogen-phosphorus nutrition can influence the percentage ratio of higher fatty acids composition.
\end{abstract}

Keywords: phosphorus and nitrogen nutrition of oilseed rape, yield of rapeseed, oil and higher fatty acids content in rapeseed 


\section{INTRODUCTION}

Oilseed rape began to become one of the most important oil crops within the last two decades. Yield and quality of rapeseed mostly depend on the genetic power of the growing varieties and the environmental conditions (Suzer, 2015). Nitrogen $(\mathrm{N})$ is the decisive nutrient for oilseed rape affected vegetative and reproductive both during vegetative and reproductive growing phases. Amount of biomass production depends on nitrogen treatment, what is a determining factor for both dry matter creation and its subsequent partition among plant tissues (Barłóg and Grzebisz, 2004).

In oilseed rape growth, phosphorus (P) is one of basic plant nutrient. The ability of the crop react to the other nutrients is limited by phosphorus nutrition availability in the soil. The inadequate levels of phosphorus supply cause impairment of genetic processes such as cell division and plant growth. Hence, the plants with phosphorus deficiency may mature slower than plants with adequate phosphorus amounts.

The stunted growth caused by deficiency of phosphorus was in correlation with smaller leaf area and decreasing amount of leaves (Zambrosi et al., 2014). The lack of phosphorus in the soil is a global problem. More than 70\% of the world's soil has very low phosphorus content and thus is restricted to plant growth. Long-term phosphorus pumping from soil reserves is caused by an imbalance in phosphorus inputs and outputs, when increased inputs mainly due to the cultivation of more efficient varieties and unilateral increase of production by nitrogen fertilization (Kulhánek et al., 2017).

Oilseed rape is a specific type of oilseed plant associated with high quality oil. Rapeseed oil is a distinguished edible oil which is also determined by a relatively high proportion of unsaturated fatty acids such as linoleic acid (C18:2), a-linolenic acid (C18:3) and oleic acid (C18:1) that are classified as essential unsaturated fatty acids (EFAs) (Narits, 2010). The average content of these main fatty acids (FA) in oil of currently grown cultivars of oilseed rape is for oleic acid 59\%-68\%, linoleic acid 17\%-21\% and linolenic acid 7.8\%-10\% (Scarth and McVetty, 1999). Rapeseed oil has very low content of saturated fatty acids than other oil plants and a relatively high content of basic fatty acids and at optimal 2: 1 ratios (Zatonski et al., 2008). It has less than $2 \%$ erucic acid and its meal has less than $30 \mu \mathrm{g}$ of glucosinolates (El-Nakhlawy and Bakhashwain, 2009). Moreover it contains 40\%-45\% oil and 39\% protein (Molazem et al., 2013). Oil quality may be improved by developing cultivars with a reduced content of polyunsaturated FA and an increased content of oleic acid (Scarth and McVetty, 1999). The reduction of linolenic acid to $2 \%-3 \%$ in rapeseed and the increase of oleic and linoleic acid to $80 \%$ and $35 \%$, respectively, has been an important breeding objective (Carré et al., 2003).
The aim of the present study was to monitor the effect of increasing doses of phosphorus on yield, oil and higher fatty acids content in rapeseed.

\section{MATERIALS AND METHODS}

The polyfactorial experiments were realized on 02 September 2013 and on 22 August 2014 in Mojmírovce $\left(48^{\circ} 11^{\prime} 283.6^{\prime \prime} \mathrm{N}, 1^{\circ} 59^{\prime} 32.1^{\prime \prime} \mathrm{W}\right)$. Hybrid Artoga was used in both experimental years. The trials were established by split plot design with randomized blocks in three replications, where plot size was $600 \mathrm{~m}^{2}$. As the previous crop was used the winter wheat (Triticum aestivum L.) in yaer 2013 and also 2014. Experimental field in Mojmírovce belongs to the corn production area with altitude of $140 \mathrm{~m}$ a.s.l. Climatic region is very warm, dry with mild winters. Climatic conditions of experimental area are defined by the average annual temperature $11.9^{\circ} \mathrm{C}$ and average annual precipitations $436.7 \mathrm{~mm}$. More precise indications of weather conditions are stated in Tab. I and II. Observed years 2013/2014 and 2014/2015 in experimental field were not equal in precipitation and temperatures. It was evaluated according to Kožnárová and Klabzuba (2002). There was the average temperature for months II.-VI. higher than long-term average, in experimental year 2013/2014. Compared to the long-term average, there was fall of average temperature by $3.1^{\circ} \mathrm{C}$ in months III.-V. Total precipitation for months II.-VI. was by $12.0 \mathrm{~mm}$ higher than long-term average. The average temperature for months II.-VI. fall by $2.1^{\circ} \mathrm{C}$ compared to long-term average in experimental year $2014 / 2015$. It means a decrease by $49.1 \%$ in relative percentage for months III.-V. Total precipitation for months II.-VI. was by $65.5 \mathrm{~mm}$ lower than the long-term average. It represents a decrease by $43.1 \%$.

Predominant soil type is created by the Luvic Chernozem on loess (Societas pedologica slovaca, 2014). The results of agrochemical soil analysis (26 August 2013 and 15 August 2014) are stated in Tab. III. The table shows that phosphorus content in soil was low in both experimental years.

In a split plot trial was observed the influence of phosphorus addition to nitrogen nutrition on yield, oil and higher fatty acids content in rapeseed. The experiment was based on three variations of fertilizer treatments. The first treatment was control without fertilization. Treatments $2_{\mathrm{U}}$ and $3_{\mathrm{p}}$ were fertilized by the same total dose of nitrogen $240 \mathrm{~kg} \cdot$ ha $^{-1}$. Treatment $2_{\mathrm{U}}$ was fertilized by Urea $(46 \% \mathrm{~N})$ and treatment 3 p by Amofos (12\% N, 23\% P) at growth stage $\mathrm{BBCH} 15$ (5-6 leaves unfolded). There was applied CAN (27\% N) at growth stage $\mathrm{BBCH} 20$ (rosette stage) and UAN (39\% N) at growth stages $\mathrm{BBCH} 30$ (beginning of stem elongation) and $\mathrm{BBCH} 51$ (bud formation), at both treatments. Doses of nitrogen and phosphorus are stated in Tab. IV. 
I: The sum monthly precipitation in experimental years 2013/2014 and 2014/2015 in Mojmírovce

\begin{tabular}{|c|c|c|c|c|c|c|c|}
\hline \multirow[b]{2}{*}{ Month } & \multirow{2}{*}{$\begin{array}{c}\text { Long- } \\
\text { term } \\
\text { average }\end{array}$} & \multicolumn{2}{|r|}{2013} & \multicolumn{2}{|r|}{2014} & \multicolumn{2}{|r|}{2015} \\
\hline & & $\begin{array}{l}\text { Precipitation } \\
(\mathrm{mm})\end{array}$ & $\begin{array}{c}\text { Evaluation } \\
\text { of normality }\end{array}$ & $\begin{array}{l}\text { Precipitation } \\
(\mathrm{mm})\end{array}$ & $\begin{array}{c}\text { Evaluation } \\
\text { of normality }\end{array}$ & $\begin{array}{l}\text { Precipitation } \\
(\mathrm{mm})\end{array}$ & $\begin{array}{c}\text { Evaluation } \\
\text { of normality }\end{array}$ \\
\hline I. & 32.9 & 67.3 & very wet & 38.2 & normal & 82.0 & extraordinary wet \\
\hline II. & 29.2 & 70.1 & very wet & 39.5 & normal & 18.5 & normal \\
\hline IV. & 36.9 & 45.5 & normal & 51.5 & wet & 19.5 & dry \\
\hline V. & 60.5 & 104.2 & wet & 84.7 & wet & 74.5 & normal \\
\hline VI. & 59.0 & 21.5 & very dry & 34.6 & dry & 8.0 & extraordinary dry \\
\hline $\mathrm{X}$. & 35.9 & 31.4 & normal & 38.0 & normal & - & - \\
\hline XI. & 45.4 & 89.5 & very wet & 21.5 & dry & - & - \\
\hline XII. & 42.3 & 8.5 & very dry & 67.5 & wet & - & - \\
\hline
\end{tabular}

(the evaluation of month precipitation normality according to the long-term average of 1982-2013)

II: The average monthly temperatures in experimental years 2013/2014 and 2014/2015 in Mojmírovce

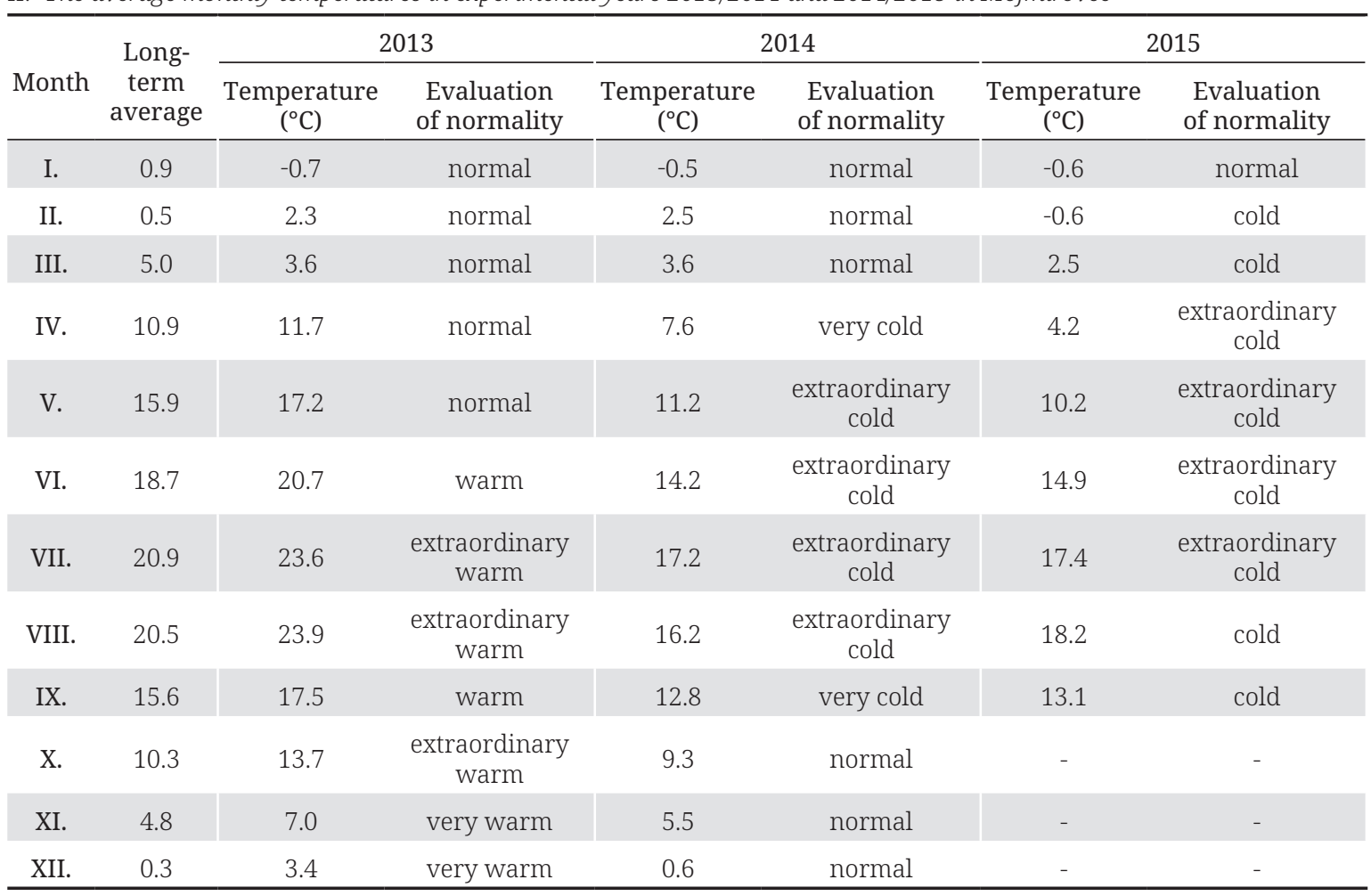

(the evaluation of month air temperature normality according to the long-term average of 1982-2013)

The influence of phosphorus supply on production and quality of rapeseed was analysed after the harvest on 25 June 2014 and on 7 July 2015 by harvester Claas Lexion 770. The quality of achieved rapeseed was performed according to the slovak standard STN 4610111-28. The oiliness was determined by the extraction method with using petroleum ether (50/70). For extraction was used the apparatus DET-GRAS N (JP Selecta S.A., Spain). A superfluous extractant was distilled after the extraction. The achieved oil was drained and weighed. Fatty acids were determined by gas chromatography. 
III: Agrochemical characteristics of soil before trial establishment

\begin{tabular}{|c|c|c|}
\hline \multirow{2}{*}{ Type of soil analysis } & \multicolumn{2}{|c|}{ Content of available nutrients in mg.kg-1 } \\
\hline & $2013 / 2014$ & $2014 / 2015$ \\
\hline $\mathrm{N}_{\text {min }}=$ mineral nitrogen $=\mathrm{N}-\mathrm{NH}_{4}^{+}$and $\mathrm{N}-\mathrm{NO}_{3}^{-}$ & 11.4 & 7.0 \\
\hline $\mathrm{N}-\mathrm{NH}_{4}^{+}$(colorimetry, Nessler reagent) & 4.8 & 3.8 \\
\hline 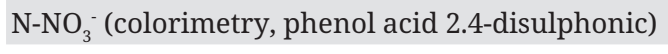 & 6.6 & 3.2 \\
\hline P-available (Mehlich III-colorimetry) & 18 & 28 \\
\hline K-available (Mehlich III-flame photometry) & 165 & 233 \\
\hline Mg-available (Mehlich III-AAS) & 393 & 353 \\
\hline Ca-available (Mehlich III-flame photometry) & 5,450 & 2,170 \\
\hline S-available (ammonium acetate solution) & 2.5 & 1.3 \\
\hline $\mathrm{pH} / \mathrm{KCl}$-exchangable reaction & 6.6 & 6.8 \\
\hline
\end{tabular}

IV: Treatments of oilseed rape nutrition in experimental years 2013/2014 and 2014/2015 in Mojmírovce

\begin{tabular}{|c|c|c|c|c|c|c|c|c|c|c|}
\hline \multirow{3}{*}{ Treatment } & \multicolumn{8}{|c|}{ Fertilization level in kg.ha-1 } & \multirow{2}{*}{\multicolumn{2}{|c|}{ The total dose in kg.ha }} \\
\hline & \multicolumn{2}{|c|}{ BBCH 15} & \multicolumn{2}{|c|}{ BBCH 20} & \multicolumn{2}{|c|}{ BBCH 30} & \multicolumn{2}{|c|}{ BBCH 51} & & \\
\hline & $\mathrm{N}$ & $\mathrm{P}$ & $\mathrm{N}$ & $\mathrm{P}$ & $\mathrm{N}$ & $\mathrm{P}$ & $\mathrm{N}$ & $\mathrm{P}$ & $\mathrm{N}$ & $\mathrm{P}$ \\
\hline $1_{0}$ & 0 & 0 & 0 & 0 & 0 & 0 & 0 & 0 & 0 & 0 \\
\hline $2_{U}$ & 46 & 0 & 84 & 0 & 80 & 0 & 30 & 0 & 240 & 0 \\
\hline $3_{p}$ & 46 & 88 & 84 & 0 & 80 & 0 & 30 & 0 & 240 & 88 \\
\hline
\end{tabular}

For statistically evaluation of achieved production and quality was used analysis of variance. By LSD test were tested differences between variants of treatment in program Statgraphics Plus 5.1 (Statgraphics Technologies, Inc., Virginia).

\section{RESULTS AND DISCUSSION}

Macroelements nitrogen and phosphorus are considered very important in oilseed rape nutrition. There was observed effect of nitrogen and phosphorus nutrition on yield, oil and higher fatty acids content in rapeseeds, in two years experiment. The highest average yield (3.9 t.ha-1) was reached at treatment $3_{p}$, where nitrogen and phosphorus was applied (Tab. V). There was found statistically significant difference between treatment $3_{\mathrm{p}}$ and control treatment, as well as between treatment $3_{\mathrm{p}}$ and treatment $2_{\mathrm{U}}$, where no phosphorus was applied, in this experiment. Similarly, Brennan and Bolland (2009) used doses of nitrogen, doses of phosphorus and combination of nitrogen and phosphorus. Significantly higher yield of seeds was found at treatment, where nitrogen was applied with phosphorus. Also Cheema et al. (2001) used fertilizer at $90 \mathrm{~kg} \cdot \mathrm{ha}^{-1} \mathrm{~N}$ and $26 \mathrm{~kg} \cdot \mathrm{ha}^{-1} \mathrm{P}$. It significantly increased seed yield in both experimental years. All in all, reached yield at treatment 3 p was by $44.1 \%$ and $53.1 \%$ higher compared to treatment $1_{0}$ and $2_{\mathrm{U}}$ in experimental year 2013/2014,

V: Effect of nitrogen and phosphorus nutrition on yield of oilseed rape

\begin{tabular}{|c|c|c|c|c|c|}
\hline \multirow{2}{*}{ Treatment } & \multicolumn{5}{|c|}{ Yield in t.ha-1 } \\
\hline & $2013 / 2014$ & $2014 / 2015$ & Average 2013/2014 and 2014/2015 & Relatively in \% & P-value \\
\hline $1_{0}$ & 3.4 & 1.4 & $2.4 \mathrm{aA}$ & 100.0 & \multirow{3}{*}{$0.0070^{*}$} \\
\hline $2_{U}$ & 3.2 & 2.8 & $3.0 \mathrm{aAB}$ & 125.0 & \\
\hline $3 p$ & 4.9 & 2.9 & $3.9 \mathrm{bA}$ & 162.5 & \\
\hline LSD treatment $_{0.05}$ & - & - & 0.8 & - & \\
\hline LSD treatment $_{0.01}$ & - & - & 1.2 & - & \\
\hline
\end{tabular}

Averages indicated by different letters are statistically significantly different on the significance level of $a \leq 0.05$ (small letters) and $a \leq 0.01$ (capital letters)

${ }^{*}$ P-value is statistically significant $(\mathrm{P}<0.05)$ 
VI: Average yield of oilseed rape

\begin{tabular}{cccc}
\hline Year & Yield in t.ha ${ }^{-1}$ & LSD test $_{0.05}$ & LSD test $_{0.01}$ \\
\hline $2013 / 2014$ & $3.9 \mathrm{bB}$ & 0.7 & 1.0 \\
$2014 / 2015$ & $2.3 \mathrm{aA}$ & & $0.0006^{*}$ \\
\hline
\end{tabular}

Averages indicated by different letters are statistically significantly different on the significance level of a $\leq 0.05$ (small letters) and $a \leq 0.01$ (capital letters)

*P-value is statistically significant $(\mathrm{P}<0.05)$

VII: Effect of nitrogen and phosphorus nutrition on oil content in seed of oilseed

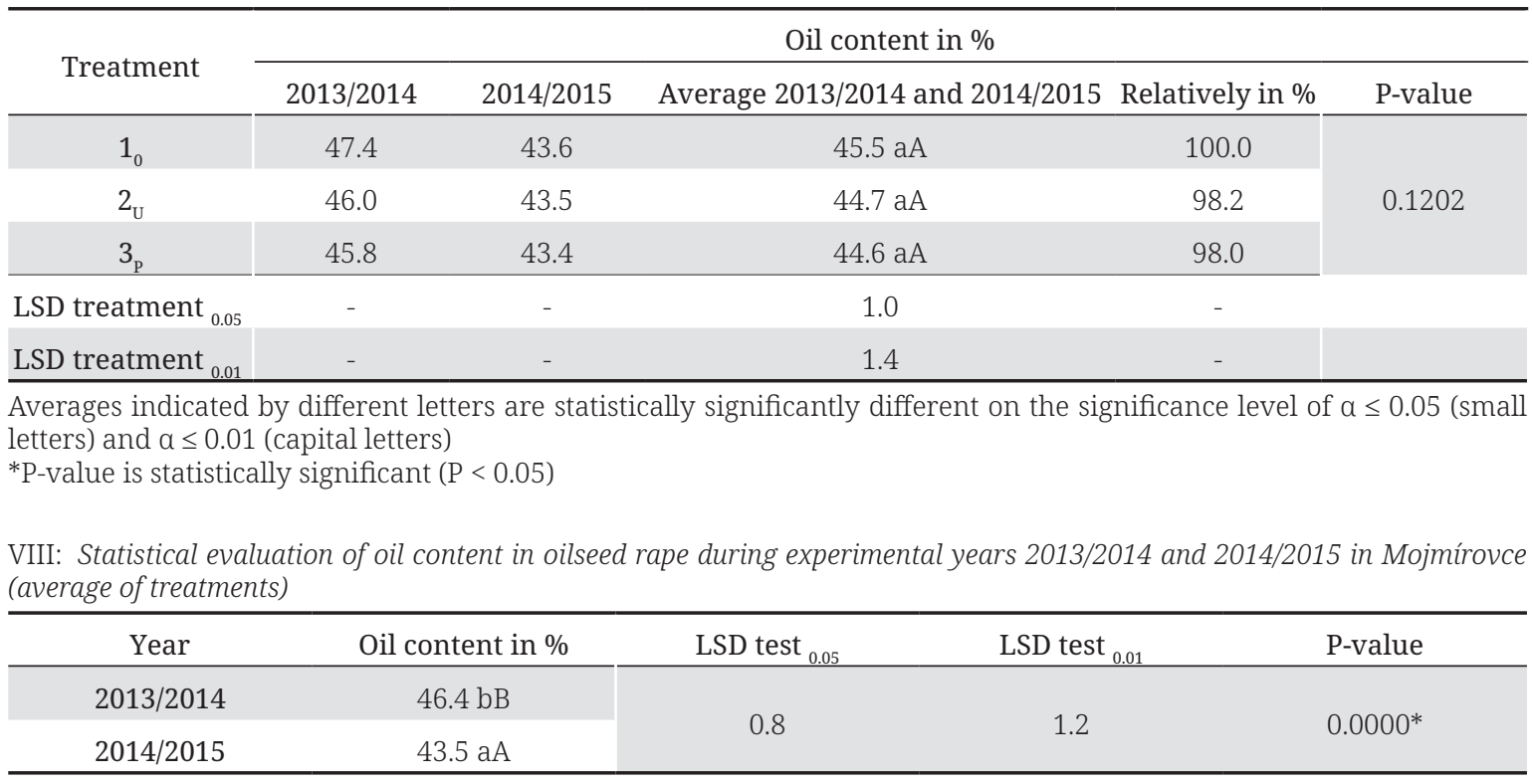

Averages indicated by different letters are statistically significantly different on the significance level of a $\leq 0.05$ (small letters) and $a \leq 0.01$ (capital letters)

*P-value is statistically significant $(\mathrm{P}<0.05)$

Both experimental years were unequal in precipitation and temperatures. Yields were strongly affected by different weather conditions. The average yield in experimental year 2013/2014 was by $41.0 \%$ higher than average yield in year 2014/2015 (Tab. VI). The difference is statistically highly significant.

According to Süzer (2007) using high doses of nitrogen fertilizers can increase amount of seed protein rate and cause to decrease the oiliness. However for higher achieved yield from per hectare may the crop decrease the oiliness. Using high doses of nitrogen fertilizer during vegetation of oilseed rape can decrease the oil of the harvested crop. The average oil content fluctuated from $44.6 \%$ to $45.5 \%$ (Tab. VII). The highest average oil content was reached at treatment 1 , where any nitrogen was not applied. But the difference among treatments is not statistically significant. Also Cheema et al. (2001) found the highest average oil content $43.0 \%$ at control treatment. Oil content decreased when doses of nutrients, especially nitrogen, increased. Similar results were recorded by Asare and Scarisbrick (1995) and Hocking et al. (1997). According to Forster (1977) and Süzer (2007, 2010) phosphorus supply in amount of commercial dosage have not any influence oiliness of rapeseed. Also Brennan and Bolland (2006) stated that application of phosphorus had no effect on concentration of oil and protein in seeds. For rapeseed production, responses to applied nitrogen always occur whereas responses to applied phosphorus are rare, but if soil phosphorus testing indicates likely phosphorus deficiency, both phosphorus and nitrogen fertilizer need to be applied. On the contrary, Motlagh et al. (2012), Said-Al Ahl et al. (2016) and Ahmed (2018) reported that phosphorus significantly increased oil content in rapeseed.

Unequal weather conditions were reflected in oil content (Tab. VIII). There was statistically highly significant higher average oil content by $6.7 \%$ in year 2013/2014 characterized by higher temperatures and higher rainfall than experimental year 2014/2015.

The amount of saturated (SFAs-without double bonds) and monounsaturated (MUFAs-with one double bond) and polyunsaturated fatty acids (PUFAs-with two or up to six double bonds) was significantly affected by the growth season, sowing date, vermicompost, genotype and interaction effect of sowing date, genotype and nutrition (Joughi et al., 2018). Unbalanced nitrogen fertilization in oilseed rape growing season may change harvested seed fatty acid profile and glucosinolate contents (Süzer, 2010). 
IX: Content of fatty acids in rapeseed in experimental years 2013/2014 and 2014/2015 in Mojmírovce

\begin{tabular}{|c|c|c|c|c|c|c|c|c|}
\hline \multirow{4}{*}{ Fatty acid } & \multicolumn{8}{|c|}{ Content of fatty acids in $\%$} \\
\hline & \multicolumn{4}{|c|}{ Experimental year 2013/2014 } & \multicolumn{4}{|c|}{ Experimental year 2014/2015 } \\
\hline & \multicolumn{3}{|c|}{ Treatment } & \multicolumn{5}{|c|}{ Treatment } \\
\hline & $1_{0}$ & $2_{U}$ & $3_{\mathrm{p}}$ & P-value & $1_{0}$ & $2_{\mathrm{U}}$ & $3_{\mathrm{p}}$ & P-value \\
\hline capric acid & 0.0 & 0.0 & 0.0 & - & 0.0 & 0.0 & 0.0 & - \\
\hline lauric acid & 0.0 & 0.0 & 0.0 & - & 0.0 & 0.0 & 0.0 & - \\
\hline myristic acid & 0.0 & 0.0 & 0.0 & - & 0.0 & 0.0 & 0.0 & - \\
\hline palmitic acid & $4.7 \mathrm{abA}$ & $4.7 \mathrm{aA}$ & $4.8 \mathrm{bA}$ & 0.0590 & $4.3 \mathrm{aA}$ & $4.5 \mathrm{bB}$ & $4.5 \mathrm{bB}$ & $0.0019 *$ \\
\hline palmitoleic acid & $0.2 \mathrm{aA}$ & $0.2 \mathrm{aA}$ & $0.2 \mathrm{aA}$ & 0.3617 & $0.1 \mathrm{aA}$ & $0.1 \mathrm{aA}$ & $0.1 \mathrm{aA}$ & 1.0000 \\
\hline stearic acid & $1.1 \mathrm{aA}$ & $1.1 \mathrm{aA}$ & $1.1 \mathrm{aA}$ & 0.8869 & $1.6 \mathrm{bB}$ & $1.5 \mathrm{aA}$ & $1.5 \mathrm{aAB}$ & $0.0113^{*}$ \\
\hline oleic acid & $64.6 \mathrm{bB}$ & $63.4 \mathrm{aA}$ & $63.3 \mathrm{aA}$ & $0.0003^{*}$ & $65.9 \mathrm{bB}$ & $64.7 \mathrm{aA}$ & $64.7 \mathrm{aA}$ & $0.0091^{*}$ \\
\hline linoleic acid & $20.3 \mathrm{aA}$ & 20.9 bB & $21.0 \mathrm{bB}$ & $0.0002 *$ & $20.3 \mathrm{aA}$ & 21.2 cC & $21.1 \mathrm{bB}$ & $0.0000^{*}$ \\
\hline linolenic acid & $8.3 \mathrm{aA}$ & $8.9 \mathrm{cB}$ & $8.7 \mathrm{bB}$ & $0.0015^{*}$ & $6.9 \mathrm{aA}$ & $7.0 \mathrm{bB}$ & $7.0 \mathrm{bB}$ & $0.0082^{*}$ \\
\hline arachidic acid & $0.9 \mathrm{aA}$ & $0.9 \mathrm{bA}$ & $1.0 \mathrm{cB}$ & $0.0020^{*}$ & $0.5 \mathrm{abA}$ & $0.5 \mathrm{aA}$ & $0.5 \mathrm{bA}$ & $0.0362^{*}$ \\
\hline arachidonic acid & 0.0 & 0.0 & 0.0 & - & 0.0 & 0.0 & 0.0 & - \\
\hline behenic acid & 0.0 & 0.0 & 0.0 & - & 0.0 & 0.0 & 0.0 & - \\
\hline erucic acid & 0.0 & 0.0 & 0.0 & - & 0.4 & 0.4 & 0.4 & - \\
\hline lignoceric acid & 0.0 & 0.0 & 0.0 & - & 0.1 & 0.2 & 0.4 & - \\
\hline
\end{tabular}

Effect of nitrogen and phosphorus nutrition on higher fatty acids in rapeseed was also observed in this experiment (Tab. IX). Oleic acid (MUFA) is the most represented in rapeseed. Its content fluctuated from $63.3 \%$ to $64.6 \%$ in year $2013 / 2014$ and from $64.7 \%$ to $65.9 \%$ in year $2014 / 2015$. Its content depends on dose of nitrogen. Mostly it is in negative correlation. Phosphorus application stabilized content of arachidic and palmitic (SFAs) acid. Content of these acids was lower at other treatments of nutrition. There were only little differences in content of other observed acids, among treatments. Škarpa and Lošák (2008) found no significant change of fatty acids content after nitrogen and phosphorus application. But nitrogen fertilization increased the concentration of oleic acid and decreased linoleic acid (essential PUFA) content. The concentration of observed fatty acids was not markedly effected by phosphorus application. As Zhang et al. (2015) stated, analysis of seven fatty acids revealed as light decrease in the contents of erucic acid (MUFA) and arachidonic acid (essential PUFA) with the increase in nitrogen application level, but no obvious change in the contents of palmitic acid, stearic acid, oleic acid, linoleic acid and linolenic acid.

\section{CONCLUSION}

Effect of phosphorus and nitrogen nutrition and its effect on yield of seed, oil and higher fatty acids in rapeseed was monitored in experiment based in experimental years 2013/2014 and 2014/2015 in terms of agricultural cooperative in Mojmírovce. The highest average yield 3.9 t.ha ${ }^{-1}$ was reached at treatment 3 , where phosphorus was applied. It means statistically significant yield increase by $30 \%$ compared to treatment $2_{U}$, where any phosphorus was not applied. Oil content was not statistically significant affected by phosphorus nutrition. Nitrogen and nitrogen-phosphorus nutrition at treatments $3_{\mathrm{P}}$ and $2_{\mathrm{U}}$ high statistically decreased oleic acid content and increased content of linoleic and linolenic acid in both experimental years. Percentage ratio of higher fatty acids composition changed in dependence on nitrogen and phosphorus application, as well as on different weather conditions in both experimental years.

\section{Acknowledgements}

The research and preparation of this article was supported by resources of the project VEGA No. 1/0325/17. 


\section{REFERENCES}

AHMED, R. M. 2018. Oil percent and unsaturated fatty acid respose of rapeseed cultivars to nitrogen and phosphorus fertilizers in two different sowing date. Tikrit Journal for Agricultural Science, 18(4): 29-38.

ASARE, E. and SCARISBRICK, D. H. 1995. Rate of nitrogen and sulfur fertilizers on yield, yield components and seed quality of oilseed rape (Brassica napus). Field Crops Research, 44(1): 41-46.

BAREÓG, P. and GRZEBISZ, W. 2004. Effect of timing and nitrogen fertilizer application on winter oilseed rape (Brassica napus L.). I. Growth dynamics and seed yield. Journal of Agronomy and Crop Science, 190(5): 305-313.

BRENNAN, R. F. and BOLLAND, M. D. A. 2006. Effect of fertiliser phosphorus and nitrogen on the concentrations of oil and protein in grain and the grain yield of canola (Brassica napus L.) grown in south-western Australia. Australian Journal of Experimental Agriculture, 47(8): 984-991.

BRENNAN, R. F. and BOLLAND, M. D. A. 2009. Comparing the nitrogen and phosphorus requirements of canola and wheat for grain yield and quality. Crop and Pasture Science, 60(6): 566-577.

CARRÉ, P., DARTENUC, C., EVRARD, J., JUDDE, A., LABALETTE, F., RAOUX, E. and RENARD, M. 2003. Frying stability of rapeseed oils with modified fatty acid composition. In: Proceedings of the $11^{\text {th }}$ International Rapeseed Congress. 6-10 July. Copenhagen: The Royal Veterinary and Agricultural University, pp. 540-543.

CHEEMA, M. A., MALIK, M. A., HUSSAIN, A., SHAH, S. H. and BASRA, M. A. 2001. Effects of time and rate of nitrogen and phosphorus application on the growth and the seed and oil yields of canola (Brassica napus L.). Journal of Agronomy \& Crop Science, 186(2): 103-110.

EL-NAKHLAWY, S. and BAKHASHWAIN, A. 2009. Performance of canola (Brassica napus L.) seed yield, yield components and seed quality under the effects of four genotypes and nitrogen fertilizer rates. Meteorology, Environment \& Arid Land Agriculture Science 20(2): 33-47.

HOCKING, P. J., RANDALL, P. J., DEMARCO, D. and BAMFORTH, I. 1997. Assesment of the nitrogen status of field grown canola (Brassica napus L.) by plant analysis. Australian Journal of Experimental Agriculture, 37(1): 83-92.

JOUGHI, E. S. G., HERVAN, E. M., RAD, A. H. S. and NOORMOHAMADI, G. H. 2018. Fatty acid composition of oilseed genotypes as affected by vermicompost application and different thermal regimems. Agronomy Research, 16(1): 230-242.

KOŽNÁROVÁ, V. and KLABZUBA, J. 2002. Recommendation of World Meteorological Organization to describing meteorological or climatological conditions [in Czech: Doporučení WMO pro popis meteorologických, resp. klimatologických podmínek definovaného období]. Rostlinná výroba, 48(4): 190-192.

KULHÁNEK, M., ČERNÝ, J., BALÍK, J., SEDLÁŘ, O. and SURAN, P. 2017. Soil phosphorus fractionation [in Czech: Frakcionace půdního fosforu]. In: Proceendigs of $23^{\text {nd }}$ International Conference on Reasonable Use of Fertilizers. 30 November. Prague: Czech University of Life Sciences Prague, pp. 57-64.

MOLAZEM, D., AZIMI, J. and DIDEBAN, T. 2013. Measuring the yield and its components, in the Canola in different planting date and plant density of the west Guilan. International Journal of Agriculture and Crop Sciences, 6(12): 869-872.

MOTLAGH, S. M., PIRZAD, A. and DELKHOSH, B. 2012. Effect of irrigation disruption and biological phosphorus on the biomass and seed yield of canola (Brassica napus L.). International Journal of Agriculture and Crop Sciences, 4(1): 489-495.

NARITS, L. 2010. Effect of nitrogen rate and application time to yield and quality of winter oilseed rape (Brassica napus L. var. oleifera subvar. biennis). Agronomy Research, 8(3): 671-686.

SAID-AL AHL, H. A. H., MEHANNA, H. M. and RAMADAN, M. F. 2016. Impact of water regime and phosphorus fertilization and their interaction on the characteristics of rapeseed (Brassica napus) and fatty acid profile of extracted oil. Communications in Biometry and Crop Science, 11(1): 64-76.

SCARTH, R. and MCVETTY, P. 1999. Designer oil canola a review of new food-grade Brassica oils with focus on high oleic, low linoleic types. In: Proceedings of the $10^{\text {th }}$ International Rapeseed Congress. Canberra.

SOCIETAS PEDOLOGICA SLOVACA. 2014. Morphogenetic soil classification system of Slovakia. Basal reference taxonomy [in Slovak: Morfogenetickcý klasifikačný systéme pôd Slovenska. Bazálna referenčná taxonómia]. Bratislava: NPPC-VÚPOP Bratislava.

SÜZER, S. 2007. Production and importance of canola in crop rotation in Turkey. In: $1^{\text {st }}$ National Oil Seed Crops and Biodiesel Symposium in Turkey. Samsun, 28-31 May, pp. 277-283.

SÜZER, S. 2010. Effects of potassium fertilization on sunflower (Helianthus annuus L.) and canola (Brassica napus ssp. oleifera L.) growth. In: Proceedings of the regional workshop of the international potash institute in Turkey. Antalya, 22-25 November. 
SÜZER, S. 2015. Effects of plant nutrition on canola (Brassica napus L.) Growth. Trakya University Journal of Natural Sciences, 16(2): 87-90.

ŠKARPA, P. and LOŠÁK, T. 2008. Changes in selected production parameters and fatty acid composition of sunflower (Helianthus annuus, L.). Acta Universitatis Agriculturae et Silviculturae Mendelianae Brunensis, 56(5): 203-210.

ZAMBROSI, F. C. B., RIBEIRO, R. V., MARCHIORI, P. E. R., CANTARELLA, H. and LANDELL, M. G. A. 2014. Sugarcane performance under phosphorus deficiency: physiological responses and genotypic variation. Plant and Soil, 386(1): 273-283.

ZATONSKI, W., CAMPOS, H. and WILLETT, W. 2008. Rapid declines in coronary heart disease mortality in Eastern Europe are associated with increased consumption of oils rich in alphalinolenic acid. European Journal of Epidemiology, 23(1): 3-10.

ZHANG, Z., SONG, H., LIU, Q., RONG, X., PENG, J., XIE, G., ZHANG, Y., CHEN, L., GUAN, C. and GU, J. 2015. Responses of seed yield and quality to nitrogen application levels in two oilseed rape (Brassica napus L.) varieties differing in nitrogen efficiency. Plant Production Science, 15(4): 265-269. 